\title{
Charles De Gaulle: The Warrior as Statesman
}

Andrew Williams

University of St Andrews, UK

ABSTRACT: De Gaulle is primarily remembered as the leader of 'Free France' between 1940 and 1945, as well as for his time as President of the Fourth and Fifth Republics. This paper explores some of the sources of his political belief system, using his military writings of the 1920s and 1930s before he became a celebrated politician. It suggests that his political views can only be understood as being influenced by his experiences as a soldier and his reflections thereon in those military writings.

[A personal note] There is a copious literature about the subject of this paper, French leader General Charles de Gaulle, a statesman, soldier and architect of global politics the like of which there have been very few in the lifetime of the man this volume celebrates. A.J.R. (John) Groom. John has often spoken to me about de Gaulle and I think it fitting that we celebrate them both together. John's attachment to France is legendary and it is largely through him that I became obsessed with the often fraught, but always fascinating, cultural, historical and political relationship between Britain and France, and through him also that I participated in attempting to deepen academic ties between the two countries. Lastly it was through him also that I met so many wonderful French academics who have since become firm friends. I would like this paper to be seen as a joint tribute to the Greatest Frenchman and, in my view, one of the greatest English scholars of International Relations of my career span, if not lifetime.

\section{Introduction}

Much of the analysis of the life of de Gaulle has appeared in the form of biography or semi biography. These biographers of de Gaulle are many, with the long-standing doyen being Jean Lacouture. Other, more recent, writers like Sudhir Hazareesingh, have rightly stressed the almost mythical nature of the General, the larger than life quality that he both encouraged and was conferred on him by detractors, rivals and admirers alike. ${ }^{1}$ De Gaulle is likewise an enigma, especially to 'Anglo-Saxons', as the French like to call the Americans and British. But he often seems to appear in the history books as a fully formed and largely unknown character on 18 June 1940, as the voice of 'Free France' on the BBC in London, 
two days after the establishment of the Vichy government of Marshall Philippe Pétain, a man who had earlier in de Gaulle's career been his mentor and superior officer. Most of the writings about de Gaulle, hagiographic and otherwise ${ }^{2}$ therefore understandably concentrate on his activities as leader of the Free French in London and Algiers, and his subsequent periods as President of the French Republic, first the Provisonal Government of 1944-46 and then the Fourth and Fifth Republics from 1958-1968.

This paper aims to try and show what were the main influences on de Gaulle before 1940 and suggest how they might have influenced his later thinking on politics and the future of France in Europe and the world. To do this I will examine a side of De Gaulle that is often neglected, his writings on strategic thinking, most of which pre-date $1940 .^{3}$ There are few extant studies of this thinking in French and English. As the study by Pierre Messmer and Alain Larcan points out, 'his short appeal of 18 June 1940 has done more for his reputation [gloire] than [all his books on military matters] put together'. ${ }^{4}$ It will also attempt to show how these writings have a close relationship to the kinds of political decisions and institutions with which his reputation is most closely connected, nearly all of which happened after 1940. His relentless political pressure on the 'Big Three' Allied leaders (Prime Minister Winston Churchill, President Franklin Delano Roosevelt and Marshall Joseph Stalin) to have France taken seriously as both a wartime ally and as a participant in the planning of the post - war world is one such nexus. ${ }^{5}$ But it is in the future relationship which de Gaulle came to believe was necessary between Germany and France, as well as the future of Europe itself where I hope that my remarks will be at least suggestive of the links between his military writings and his later thoughts and actions.

Given the constraints of space, I will subsequently sketch out some of de Gaulle's views about the future of Europe after 1945, and show how they most proximately connected to his military writings, and especially to his views on Germany. How could France come to terms with the enemy of five wars since 1800 , while keeping its dignity and independence and avoiding the seemingly eternal cycle of revenge and reparation? If there had been enough space, I could also have looked at his attitude towards what became known as the 'Third World', often in disagreement with the 'Anglo - Saxon' Powers (Britain and the United States), though space is lacking to do it properly in this short paper. In particular de 
Gaulle was a major player in a very different view of post - war decolonisation, with his support for the notion of 'non -alignment', as well as with his views on the necessity for a rapprochement with Communist states like the USSR, China and Vietnam. ${ }^{6}$

So the central question here is to what extent we can see the principles of De Gaulle's pre war musings, which Lacouture rightly calls his period as 'The Rebel' (1890-1944) being carried through into his post - war reincarnation as 'The Ruler' (1945 -1970), even if the two categories are of course not fully in coincidence with his periods of major influence. After all, De Gaulle was only a 'Rebel' for the Vichy Government in France of 1940-44, not for many millions of French and other admirers. Equally he was not any kind of 'Ruler' between 1946 and 1958, though he came back in triumph in the latter year. ${ }^{7}$

\section{Charles De Gaulle: 'mystic' or 'politician'?}

This fascination with de Gaulle has varied in intensity over the years, often in line with whether his views are seen as vieux jeu [old hat] or because he has returned to fashion as a visionary, a man way in advance of his time. A bit like his roughly exact contemporary Jean Paul Sartre $(1905-1980),{ }^{8}$ he has been alternately feted, ridiculed or ignored, though neither man would have liked the comparison. They may also both suffer from having been (largely) correct, reminding lesser mortals of the inadequacies of their tunnel vision, but alienating them by the seeming arrogance of their expression of this truth. This was a problem acknowledged by de Gaulle himself. When the founder of the nationalist movement Action Française supporter of Vichy, Charles Maurras, was being tried for having collaborated with the Germans after the war de Gaulle is said to have commented that he had been driven 'fou à cause de toujours avoir raison' ['driven mad by always being right']. And the French novelist Claude Mauriac recounts how de Gaulle's' successor as French President Georges Pompidou in 1970 said that 'on n'a jamais raison contre l'Histoire... il faut encore que les évenéments vous donnent raison' [one is never right against history... [subsequent] events have to prove you were right']. ${ }^{9}$ In both cases they were right or wrong according to historical circumstance. But de Gaulle believed he was right nearly all the time, he had 'une certaine idée de la France'. So where did he get it from? 
De Gaulle and Sartre certainly represent in the public consciousness, both within and outside France, the quintessence of what France has contributed to Western civilisation since the First World War. But whereas Sartre, and fellow intellectuals, and occasional friends, Albert Camus and Raymond Aron fought about ideas and created the hip Montparnasse culture so beloved of would - be 'existentialists', de Gaulle moved on a far more elevated stage of the theory and practice of war, peace and statesmanship. In all of these he excelled, alternately delighting and enraging a global audience over a thirty-year period from 1940 to his death in 1970. It is important to remember that he emerged from almost total obscurity, a recently promoted Brigadier in the annihilated French Army to be the symbol and reality of a 'Free' France that demanded to be readmitted to the top table of global politics.

It is the measure of his greatness that these three categories of commentator often held him in great esteem and with dismay simultaneously, British Prime Minister Winston Churchill being maybe the best example of the phenomenon. ${ }^{10} \mathrm{His}$ detractors often went further than the use of the epithet 'mythical'. The Republican Presidential candidate of 1940 Wendell Willkie was overheard by Free French officials in Washington in late 1942 saying de Gaulle was 'quelque chose entre un politicien et un mystique' [something between a politician and a mystic]. ${ }^{11}$ But whereas being labelled a 'mystic' in English was by no means a compliment, in French it has a totally different connotation. To quote the seminal French political thinker Charles Péguy, 'tout commence en mystique et finit en politique.' This could be roughly translated as: 'Mysticism has the ring of truth, dragged through the mud by reality'. In the context of a France demoralised by the crushing defeat of 1940, 'mystique' meant the slim possibility of renewal. Andrew Shennan has written that the defeat of 1940 Ilaid bare a profound national crisis [which] was perceived to permeate every aspect of French life-economic, social, demographic, political, even ethical' and this required a 'search for a new national mystique ${ }^{\prime 12}$ De Gaulle seems to provide us with an answer as to how that was achieved, a man of the hour. But he was not one that was by any means recognised as such by most of France and the world in 1940 and for a long time afterwards.

\section{De Gaulle: Rebel Strategist}


De Gaulle was above all else a soldier. He served with distinction in the First World War as an infantry officer, and was wounded and captured during the Battle of Verdun in 1916, spending the rest of the war in captivity in Germany, from which he tried to escape on five occasions. But he was a most unusual soldier. As Lacouture puts it, his 'life [was] lived on the fringes of the routine activities even of the prescribed practices, in a country whose fragility he continually denounced, and in the bosom of an army that was divided by him in person, among others... in [a] constant state of rebellion'. Even as a lieutenant in 1912, in a unit commanded by (then) Colonel Philippe Pétain, an advocate 'of the superiority of fire power over offensive - a thesis that proved prophetic in 1914', de Gaulle disagreed with his commander. Lacouture reminds us that de Gaulle was 'in complete intellectual dissidence' with Pétain, 'fill[ing] his notebooks with praise of movement and attack, they alone being decisive in war'. By 1917 he was giving lectures as a prisoner of war criticizing the 'strategic and tactical mistakes of the High Command'. By the time he was asked to teach at the Ecole de Guerre in 1924, 'Captain de Gaulle arrogantly maintain[ed] arguments in favour of tactics based on circumstances... not only a heretic but a relapsed heretic'. ${ }^{13}$ We will see that this tradition continued throughout the inter-war period up to and including his major breach of discipline by refusing to obey orders by raising the standard of revolt in London in June 1940. Each step of this 'heresy' was elaborated in the works that I will now consider in turn.

For he was also a thinker. Lacouture writes that he was unusual in this respect, as soldiers generally are not 'intellectuals', even in France. And if we add to that the observation that de Gaulle was also a soldier who stood up to the top echelons of the military hierarchy in his obstinate refusal to accept their views on warfare and strategy, as a lecturer at the Ecole de Guerre, it is evident that he was not the average officer. His works of the inter - war period, of which the most important are Le discorde chez l'ennemi (1924), Le Fil de l'épée (1932), Vers l'armée de metier (1934) and La France et son armée (1938) ${ }^{14}$ are without parallel in the period by a serving officer, with the exception of General Heinz Guderian, who served throughout the Second World War as the preeminent German expert on armoured warfare, summed up in his book of 1937, Achtung Panzer. ${ }^{15}$ De Gaulle' s views of the period also mirror British strategists Captain Basil Liddell Hart (who retired from the army in 1927) and General J.F.C. Fuller (who retired from the army in 1933). ${ }^{16}$ 
After his return from imprisonment in Germany and then a spell fighting with the Polish forces resisting the Bolshevik advance in the early 1920s, de Gaulle was enrolled at the Ecole de Guerre, traditionally the precursor to becoming a higher-ranking Staff Officer. He was not popular with many of his superiors as he never minced his words in criticizing the conduct of the war. In his passing out marks he was only given a note of assez bien (like being given a B- or a 2:2 Honours degree in Britain) putting him low on the list. His refusal to agree with those who taught him was a clear signal that he had to be reined in. But his saviour turned out to be his earlier commanding officer, Pétain, who was now not only the venerated Marshall and Victor of Verdun but also the 'very virtuous chief of the army's department of higher education'. His marks were reviewed and increased to 'bien'. ${ }^{17}$ De Gaulle was of course to later to condemn the Marshall to death for treason.

Discorde starts with an amazing admission, in the context of 1924, when French armies had just re-invaded the Ruhr to enforce the provisions of the Treaty of Versailles. De Gaulle's first sentence exhorts his reader to 'rendre à nos ennemis l'hommage qu'ils ont mérité par l'energie des chefs et les efforts des executants [and] l'étenue exceptionelle de qualités de guerre qu'ils montrèrent, d'un bout à l'autre du drame' ['pay proper homage to our enemy who has demonstrated the exceptional and warlike energy of its leaders and its soldiers throughout a long struggle']. He thereby implicitly criticised the failing of France's own 'chefs' and 'executants'. The German generals are praised to the skies for their abilities as commanders, as are the German people for their moral strength - both factors will assuredly obtain 'I'hommage de l'histoire.' But his praise was not without a sting, for he goes on to explain why the German army, for all its strengths, was nonetheless eventually defeated. Lacouture sums this up as being that de Gaulle stresses 'the necessity of placing the "management of the war" entirely in the hands of the political power'. Because Admiral Tirpitz and General Ludendorff, respectively heads of the German navy and army "tried to impose their own "direction of the war" on the civil power [...] they doomed the [German] Empire to ruin'. ${ }^{18}$ 
Most analyses of this book tend to stop there. But maybe the most interesting commentary is on the campaigns that de Gaulle analyses, and particularly the discussion of the differences between the attitude of Helmut von Moltke (the Elder), the German Commander in Chief of the Austrian and French campaigns of 1866 and 1870, and that of the Commander in 1914 on the Western Front, also called Helmut von Moltke (hence 'the Younger'), the nephew of the Great Man. In the first case the victory was assumed to have been won by a commander who let his subordinate generals do what they liked within the broad aims of the campaign, up to and including disobeying direct orders, and the commander of 1914 who was considered to be, according to de Gaulle, as 'laborious and learned [instruit] and, wrongly or rightly, considered by his ambitious and inconvenient [incommode] lieutenants, as only semi-energetic, indeed ailing'. The ghost of von Moltke the Elder, who had gloried in not being able to issue orders in the middle of the Battle of Sedan by only having one horse-mounted aide de camp available, and he perfectly able to fall off his horse, dominated thinking in 1914. But in 1870 de Gaulle wrote that the only French general against whom the Prussians were measured was the 'systematically inert Marshall Bazaine', while in 1914 the German forces were up against a much better French general in Joffre. The result was the glorious and improbable French victory on the Marne which in effect sealed Germany's fate, even if it took four years for this to become apparent. As in 1870 the German High Command had made a virtue of letting German forces do their own thing. But this time the High Command had, albeit primitive, aerial reconnaissance that pointed to a huge French build up and flanking movement on the Marne. Such was the weight of history that von Moltke the Younger did nothing with this intelligence and the German General that was about to be outflanked, Von Kluck, refused to believe that the French had any such advantage. De Gaulle explains this seeming idiocy by seeing the dangers of, first, the reliance on historical precedent, and, second, the post-1870 writings of Friedrich Nietzsche. This had made every German officer 'as in all of thinking Germany' believe that he was a 'superman... thus disposing each of them to see himself as being the centre of the world'. The dangers of historical and personal hubris were thus allied to the dangers of relying on the intellect. The lesson was not learned, as von Moltke the Younger's successor Erich von Falkenhayn then went on to another reverse at Verdun in 1916, a battle in which de Gaulle was both wounded and captured. 
A similar battle of minds and ideas dominated the other case studies in de Gaulle's analysis. In the second such study, on the declaration of unlimited submarine warfare, he puts the responsibility for a suicidal decision to provoke the United States into declaring war on a battle between the egos of the weak and vacillating Kaiser Wilhelm II, the founder of the Modern German navy Von Tirpitz, and the German Chancellor Bethmann Hollweg. The latter fully understood the consequences of pushing the United States, which he knew to be fundamentally opposed to involvement in Europe's war, into the conflict. Tirpitz had also provoked the formerly friendly Great Britain by his provocative statements and naval building programme into seeing Germany after about 1907 as its most likely foe, reversing many centuries of cooperation and enmity towards France. When British Secretary for War Lord Haldane, one of those most fearful of German rearmament, had proposed a truce on naval armaments, von Tirpitz had rebutted the approach, accusing Haldane's sponsor Bethmann of going soft. This personal dislike was aggravated during the war with von Tirpitz seeing it as his personal mission to destroy any idea by Bethmann that might have led to keeping the USA neutral. The Kaiser ended up supporting the admiral, through sheer personal weakness of character. Von Tirpitz used his charisma to whip up nationalist opinion in the streets and the Reichstag. The final blow to Bethmann's attempt to moderate the party of total war was the Kaiser's decision to dismiss von Falkenhayn and call the popular Marshall von Hindenburg and his deputy Ludendorff to be head of the Army. In effect the Reichstag and the Kaiser gave up control of the war to the navy and Hindenburg. This abnegation of political responsibility led to the final disaster. ${ }^{19}$

The two final case studies deploy similar psychological and political analyses to show how German commanders relied on their need for promotion and their belief in their Nietszchean moral superiority to betray their Allies and to finally topple the only sensible German politician in de Gaulle's opinion, Bethmann-Hollweg. The first of these cases shows the supreme hubris of Falkenhayn, who was prepared to sacrifice his Austro-Hungarian Allies in his desire to prove his worth at Verdun. The result was a near disaster in the first theatre of war and the second a costly and pointless stalemate at Verdun, after which, as we have noted, he was dismissed from high command. The second studies the final dive of Germany into a military dictatorship, in a very detailed analysis of voting patterns in the Reichstag, 'after which Germany let itself be led by Ludendorff' and to the 'collapse of a 
strong and valiant people'. The 'moral collapse' of the German state and population he sees as having been a consequence of the collapse of its army, but the roots of this lay in the moral defeat of the civil power. ${ }^{20}$ The parallels to what was to happen in 1940, and again in 1944, are striking, though even de Gaulle cannot have imagined in 1924 that he would play a huge role in re-establishing the moral authority of both the French army and state.

Le Fil de l'épée, 1932

Independently of de Gaulle, (by now) Marshall Pétain had decided after the war that there needed to be both a proper analysis of what had gone right and wrong in the war and how the French army might be re-designed to be better prepared for another major conflict. Apparently impressed by what he had read of Le discorde chez l'ennemi, sent to him by the author, he summoned Captain de Gaulle to see him in early 1925 and told him he would like his subordinate to help him write a book on the re-organisation question. Lacouture drily remarks that de Gaulle was in effect 'being called in as a ghost, as the great leader's penholder... the assistance of the man who was said to be the best writer in the army'. This 'assistance' was a difficult thing to refuse when the request came from the most famous soldier in France. He was certainly a bird in a gilded cage, given everything he could reasonably require, but de Gaulle quickly chafed under Pétain's guidance for a book that was supposed to be entitled Le Soldat. When Pétain then decided to go back to active service to put down a rebellion in Morocco in August 1925 de Gaulle saw this as a stab in the back for the man Pétain replaced, Marshall Lyautey, and the haughty Captain for ever more asserted that Pétain 'died in 1925, and he did not know it'.21

De Gaulle did not consult either Pétain or the then Commander in Chief of the Army Maurice Gamelin, when he tried to publish more of his views, in the Revue Militaire Française in 1934 but first in the book of 1932 he entitled Le Fil de l'épée [the edge of the sword]. The book was based on a series of lectures he gave at the Ecole de Guerre and are a summary of de Gaulle's views on the nature of the soldier, the theme of the proposed book with Pétain of course. ${ }^{22}$ The nature of these lectures was mainly to do with the ideal soldier and dwells a great deal on character, and especially that of leaders in war: 
'Wishes and hopes turn towards the leader as iron towards the magnet. When the crisis comes, it is he who is followed, it is he who raises the burden with his own arms... A kind of tidal wave sweeps the man of character to the forefront'.

We have already seen his evolving views on Pétain after 1925 and although he dedicated the book to the Marshall a lot of people detected a great arrogance, even insolence, towards his patron in the book. It comes over more as an 'essay' than as a book, as Messmer and Larcan point out, and one that they stress was written in a very classical style, to the point where de Gaulle has been described (here citing Claude Roy) as the Iast French writer to write in Latin' ${ }^{23}$ But its intentions are very clear. He was using the forum of the Ecole de Guerre itself to criticise the leadership of the army. Maybe he was even saying that the leader of 1916 was no match for the new challenges of the 1930s?

Vers l'armée de metier, 1934

De Gaulle believed in a far more radical approach to military reform than Pétain. The latter's experience at Verdun had taught him above all the benefits of a strong defensive line, one on which he believed any enemy could be broken. Such had been his experience at Verdun in 1916. And in 1916 he had been right, though his support in the late 1920s for a frontier length version of this principle was clearly with hindsight mistaken. The Maginot Line, practically complete by 1939 , was of no use against a flanking armoured attack, as de Gaulle came to realise. ${ }^{24}$ Neither was it enough to rely on the old ideas of conscription that had provided France with its waves of infantry at Verdun and beyond. By 1934 de Gaulle was convinced that what was needed was une armée de métier, ${ }^{25}$ a professional army. In so suggesting he not only upset the Marshall, he also upset the 'republican' generals like the main commander in chief for most of the 1930s, General Gamelin. Even though there were precedents in Republican circles for army reform, most famously Socialist leader Jean Jaurès's L'armée nouvelle, ${ }^{26}$ that book urged a renewal of the French revolutionary tradition of 1789 in a levée en masse, a combination of 'military and moral force', and most decidedly against what Jaurès termed 'Napoleonic tendencies'. Gamelin obviously saw de Gaulle’s views in this latter light. $^{27}$ 
De Gaulle also advocated the development of the tank and of offensive aircraft in the mid to late 1930s, weapons that had been used a bit like the machine gun at Sedan in 1870, as an isolated support for the infantry. As with the machine gun in the First World War, for de Gaulle it had become apparent that tanks and aircraft needed to be used in conjunction and en masse, which also presupposed the opposite of the Maginot mentality, a return to the dominance of the offensive. As a number of writers have pointed out, however, the French armaments industry was neither capable, or often even willing, to provide the necessary hardware. Partly this was as a result of the dire industrial relations in French industry generally in the 1930s, partly it was due to the chaotic nature of the politics of the Third Republic, and partly it was due to the economics of production. It was far more profitable for Messieurs Citroen and Renault to produce high - value motor cars than expensive prototype tanks. The French Ministers for Air before 1940, Pierre Cot and Guy La Chambre, were not able to galvanise the various French Governments in which they served to prioritise plane manufacture and the United States' Neutrality Acts made such production for a foreign Power problematic in any case.

Martin Alexander shows how French tanks were as good as any the Germans were able to produce but they were badly deployed and in too few number to count, except in a famous engagement in 1940 near the highly symbolic Chemin des Dames led by Brigadier Charles de Gaulle. ${ }^{28}$ Certainly the 1936 French Military Manual saw tanks as being used to support infantry and it was only in 1939 that two brigades of tanks were allowed to be deployed as were the German panzers, as independent units, too little and too late..$^{29}$ There is an interesting academic dispute about how ignorant of the necessities of tank warfare the French (and British) High Commands really were, that pits Douglas Porch against Elizabeth Keir. It is fair to say that Keir's views, that the Generals rather neglected the right kind of tank warfare, would have probably got de Gaulle's vote. Alexander defends the Generals, especially Gamelin, whom he says have been treated to post facto criticism that ignores their domestic constraints.

More seriously, Alexander also criticises de Gaulle, whom he believes 'showed no special clairvoyance towards military applications of aviation. ... and offered no doctrine of airarmour coordination' in l'armée de metier. ${ }^{30}$ In the febrile atmosphere after the Second 
World War, such understandings on occasion led to law suits. Alfred Fabre-Luce, a prominent French journalist who stayed in France during the occupation (and wrote a celebrated series of Journals de la France, 1940-44) was critical of de Gaulle's stance in 1940 and was imprisoned by both the Vichy and Resistance authorities for his ambivalence. But he went too far when he accused de Gaulle in 1962 of not understanding at the time the need for armour and air power. De Gaulle's lawyers took him to trial for, in effect, lèse majesté towards the President for saying so. The significance of this lies much less in the truth of the accusation than in the importance that the myth of de Gaulle in the resurrection of France had come to assume by $1962 .{ }^{31}$ When de Gaulle talked about 'une certaine idée de la France' that idea had come to mean his person and the stories he told. Fabre-Luce, who accepted the French defeat with more or less good grace in 1940, incarnated a France that de Gaulle felt he had defeated. ${ }^{32}$

La France et son armée, 1938

Even before 1940, de Gaulle was creating his own mythology, and his military writings have to also be seen in that light. Unlike his earlier books, La France et son armée, of 1938, pays homage to a different French hero from his Le fil de l'épée, no longer Pétain, but rather Charles Péguy. Péguy was an intellectual 'hero' who was killed on practically the first day of the First World War, and is quoted by de Gaulle in the Dedication as saying 'Mother, see your sons, that have fought so hard [for you]'. Péguy will be further referred to below. The book is a paean to the French profession of arms back to the Gauls. If French schoolchildren were taught in the 1930s about 'leurs ancètres les Gaullois', de Gaulle stressed their military skills. Again the prose is sonore, the linguistic equivalent of a French cathedral's vaulted ceilings, and that may have put off many Anglo-Saxons unused to such prosody. The book is a specialist text, as it was intended to be, but it was also a call to arms and a demand that France be proud of herself, a condition which de Gaulle and many others like Gamelin could see was sadly not the case in the late 1930s. He correctly saw that 'France sees itself in the mirror of its army' (reflète fidèlement au miroir de son armée). ${ }^{33}$

\section{Other Key Influences on de Gaulle}




\section{Charles Péguy and Henri Bergson}

Lacouture believes that before the First World War de Gaulle had certainly read a large variety of military writers, notably Clausewitz, but also that he had read a great deal of 'civilian' literature, typical of a 'young man shaped by a catholic education, intensely interested in history, permeated with nationalism and curious about everything'. In particular he read Maurice Barrès, as well as the founders of Action Française, the renewers of Catholic thought and 'above all [Charles] Péguy and [Henri] Bergson.' Péguy, a man from a decidedly poor background, was most famous before the First World War as the editor of the Cahiers de la Quinzaine, a periodical of great intellectual influence. Péguy is best known for his uncompromising attachment to socialism, Catholicism and nationalism, a mixture that has given him followers from the Left to the Right of French politics ever since, including de Gaulle. ${ }^{34}$ Péguy greatly admired Bergson, whom he heard lecture while he was a student at the prestigious Ecole Normale Supérieure. Bergson was the most important French philosopher of the period before the Second World War, an influential lecturer at the Sorbonne and the Collège de France (whose lectures anyone can attend) and author of many celebrated philosophical texts. As a Jew, he was subject to the Vichy anti-semitic laws, a subject of some embarrassment to Vichy Prime Minister Pierre Laval, who asked him to accept 'honorary' Aryan status. Bergson refused and died of pneumonia after queuing up in the rain for his yellow star in January $1941 .^{35}$

Unlike many other conservative, catholic Frenchmen at that time, De Gaulle did not follow Barrès, Charles Maurras and the rest of the French extreme right into the anti-semitic, ultranationalist group who condemned Captain Dreyfus to the horrors of Devil's Island purely to defend the supposed 'honour' of the French army. His intellectual revolt against what might be termed conservative conformity began even before he became a soldier. Péguy was more to his liking, a French nationalist who constantly evoked the great figures of France's past, who would have no truck with socialist pacifism, but was also a supporter of Dreyfus. He also admired Bergson's Evolution créatrice, whose notions of the superiority of intuition over intellect he saw as a major reminder of the importance of listening to God and one's instinct. De Gaulle gives Bergson prominence in Le Fil de l'épée, particularly evoking the need to trust one's instinct (or maybe even 'conscience'?) when faced with a reality that is 
in constant movement, as well as the problems of being too 'intelligent' ${ }^{36}$ Lacouture points out that Bergson is also evoked by de Gaulle in this way in La France et son armée, his most lyrical evocation of the glories of French military history. He shared Bergson's 'distrust of categories and systems', again stressing the importance of using intuition to make major decisions and to be prepared at all times to have to 'make anew'. ${ }^{37}$ Such was definitely de Gaulle's calling both as a soldier and as a politician. But it was a calling that supposed a higher moral imperative than the mere search after personal power. We can see the power of Bergsonian ideas, such as the need to trust instinct and the urge to 'make anew' in both the Appeal of June 1940 and in the decisions that led to his taking power for the second time in 1958. Ayache makes the clear link in his account of that period, for example. ${ }^{38}$ As we suggested above probably the most important aspect that de Gaulle took from Bergson was his ability to sense the moment to take a risk, to go with the gut, not the head. This is noted by all his biographers.

Other key republican soldiers in the French army before the Second World War also showed admiration for Bergson, most notably Gamelin, in 1940 the Commander in Chief of the French Army. He was subsequently put on trial in the Riom Trials of 1942 by Pétain for having allegedly failed France, along with Socialist Prime Minister Léon Blum (1936-37) and Edouard Daladier, Minister of War (1936-40) and Prime Minister (1938-40), and a variety of other ministers of the Third Republic. Although both Gamelin and de Gaulle can be considered 'intellectual' soldiers' ${ }^{39}$ and both were Dreyfusards, not a popular option among young army officers before 1914, as we have seen Gamelin had a frosty relationship with de Gaulle, whom he suspected of Boulangist tendencies. But both were cultivated men, and both shared a huge admiration for history and Bergson, Gamelin was for his best biographer '[t]he antithesis of the archetypal military philistine' ${ }^{40}$ However de Gaulle in effect treated him the same way as he had treated Pétain, with more than a dash of contempt. He always held Prime Ministers Blum and Paul Reynaud in far greater respect than either of his former commanding officers .

\section{Conclusion: Germany and Europe}


De Gaulle certainly understood the nature of the French nation and of the importance of national identity for the French and for other Europeans. That was made clear in his pre-war writings about the French army and his many speeches on the topic. As Régis Debray pointed out de Gaulle had a clearer understanding of the topic than the French Left, ${ }^{41}$ and that might still be said to be the case, even if it is beyond the scope of this paper. But he also played an inordinately important role in the evolution of the European project after the war, even if it is doubtful that he would have liked what it has now become.

For at times it did not seem that his sympathies for a European entity were very strong. In the period between January 1946 and his return to power in June 1958, he proclaimed himself convinced that Europhile politicians like Jean Monnet, ideological father of European unity, Robert Schumann, the co-founder of the European Coal and Steel Community (ECSC), as well as his former right hand man in Washington René Pleven and the signatories of the Treaty of Rome in 1957 were all traitors to France. Another generally sympathetic biographer, Ayache, compares his language about the European Defence Community (EDC) proposal of 1952 - 1954 (when it was rejected by the French Parliament) to the ravings of Captain Haddock in the comic book Tintin. He saw the EDC Treaty as an extension of attempts by the United States to control Europe, as they were also trying to do through NATO (founded in 1949), in the name of 'burden-sharing'. It was 'le suicide de la France' and he called for a return to the Maquis. But for de Gaulle the 'European' army that Truman and his Secretary of State Dean Acheson envisaged was nothing more than 'une ânerie' [asinine nonsense]. At that point his considered opinion was also that 'L'armée européenne, c'est l'armée de l'Europe. Or l'Europe n'existe pas en tant qu'entité morale et politique.' [the European army is that of Europe. But Europe does not yet exist]. ${ }^{42}$

But by 1958 he had had a miraculous conversion, his relationship with Konrad Adenauer led to one of the greatest political double acts of the Twentieth Century. From then on, notwithstanding episodes like the 'Empty Chair 'of 1965-66, (when de Gaulle refused to engage with EC's move towards a more supranational organisation) he supported a Europe that was 'l'Europe des nations'. This is a notion that has never disappeared and may indeed be said to making a comeback. For de Gaulle never stopped being a French nationalist and a believer in a Europe des nations, but he did shed the age-old French distrust of Germany. 
What he did do was to see Europe as a continent whose politics should evolve in line with French and German desires and not one that should in any way be contaminated by British or American wishes, often to the alarm of his partners in the EC like Holland and Belgium who wanted at all costs to keep the British in Europe. Only after de Gaulle fell from power in 1969 was there any possibility of a supranational development for European institutions.

So can we really say that de Gaulle's views as a soldier and man influenced his thinking on the international politics of his day, at least in Europe and in his dealings with the United States? De Gaulle's views tended to vacillate like everyone else's, but there were certain constants in his thinking that can be traced back to his own experiences in life, as a soldier in particular. Lacouture sees de Gaulle's changing views as being due to his major 'muse of history' - when he was thinking of Her and he felt 'deprived of her lessons, he sometimes seemed to vacillate, to be groping his way.' So, says Lacouture, when faced with the United States, he was often confused as 'he had no "grid" of historical references to deal with' the country. No such doubts existed when dealing with the British as there he had the 'bitterness' born out 'of excessive attachment to a past in which Hastings, Agincourt, Waterloo and Fashoda loomed large'. This was well described in La France et son armée. The same was true of Germany and Poland, with which he was not only familiar as a soldier but also as a historian. So, adds Lacouture, 'Germany was in the forefront of [his] thinking.. because the community living on either side of the Rhine belonged perfectly to the historical setting that inspired the author of Le Fil de l'épée. ${ }^{43}$

In addition de Gaulle never lost his admiration for what he had called in Discorde the moral strength and military capability of the German people. In his criticism of German tactics in $1914-18$ his bile was reserved for the political leadership. This was reinforced by what he saw in Germany during his captivity. But what if Germany could find leaders who did not abuse the moral strength of the German population but put it to positive use in a good cause? In Konrad Adenauer and, post - 1945, other German leaders de Gaulle ultimately found the kind of people he could work with. But that was not the case in the immediate aftermath of the war, and not really until he became President again after the crisis in Algeria and the foundation of the $5^{\text {th }}$ Republic. 
Certainly he wished to find German leaders who were prepared to create a Franco-German Europe, not one tainted by Anglo-Saxon compromises and an excessive intrusion of nonEuropean Powers, both of which he ascribed to both the United States and Britain, but not necessarily to Russia. That he found with Adenauer who he believed understood like him that 'national independence, the construction of Europe, peaceful East-West relations' 44 were all part of the same project. The Transatlantic and Transmanche Cold Warriors did not fit with that vision of the world.

\footnotetext{
${ }^{1}$ The English translations of Lacouture's three volume biography in French are his two volumes: Jean Lacouture, De Gaulle: The Rebel, 1890 - 1944 (London: Harvill/ Harper Collins, 1990), and; De Gaulle, Vol II: The Ruler, 1945 - 1970 (London: Harvill/ Harper Collins, 1992); Sudhir Hazareesingh, In the Shadow of the General: Modern France and the Myth of De Gaulle (Oxford: Oxford University Press, 2012). We can also cite, in English: Charles Williams, The Last Great Frenchman: A Life of General de Gaulle, (London: Wiley, 1997); Jonathan Fenby, The General: Charles de Gaulle and the France He Saved (London: Simon and Schuster, 2011).

${ }^{2}$ Other biographies in French include: François Mauriac, De Gaulle, (Paris: Grasset, 1964); Alain Peyrefitte, C'était de Gaulle (Paris: Fayard, 1994); Max Gallo, De Gaulle, (Paris: Magellan, 4 vols, 2000 - 2014, and; in one volume, Paris: Poche, 2015); Gérard Bardy, De Gaulle avait raison; le Visionnaire (Paris: Télémache, 2016).

${ }^{3}$ De Gaulle's military writings have been collected in one volume, although in this article I will use the individual texts: Charles de Gaulle, Le Fil de l'épée et autres écrits, (Paris: Plon, 1999).

${ }^{4}$ Pierre Messmer and Alain Larcan, Les écrits militaires de Charles de Gaulle (Paris: Presses Universitaires de France, 1985), p. 7.

${ }^{5}$ A relationship that I have explored at length in another article: 'France and the Origins of the United Nations, 1944-1945: "Si La France ne compte plus, qu'on nous le dise"', Diplomacy and Statecraft, Volume 28, Number 2, online, June 2017). ${ }^{6}$ To be explored in a forthcoming volume, provisionally entitled: Andrew Williams, France and the Anglo-Saxons, 1940-1970 (London: Palgrave Macmillan). This is a sister volume to: Andrew Williams, France, Britain and the United States, 1900 - 1940: A Reappraisal (London: Palgrave Macmillan, 2014).

${ }^{7}$ Georges Ayache, Le retour du Général de Gaulle (Paris: Perrin, 2015).

${ }^{8}$ Bernard-Henri Levy, Sartre: The Philosopher of the $20^{\text {th }}$ Century (Cambridge: Polity, 2003). See also: Thomas Flynn, Sartre: A Philosophical Biography (Cambridge: Cambridge University Press, 2014), and; Sarah Bakewell, At the Existentialist Café: Freedom, Being and Apricot Cocktails (London: Chatto and Windus, 2016) and; Patrick Baert, The Existentialist Moment: The Rise of Sartre as a Public Intellectual (Cambridge: Polity Press, 2016).

${ }^{9}$ Claude Mauriac, les Espaces Imaginaires (Paris: Grasset, 1975).

${ }^{10}$ François Kersaudy, Churchill and de Gaulle (London: Fontana, 1990).

${ }^{11}$ Report by the Directeur of the Sureté Générale des Armeés, 11 September 1942, De Gaulle Papers, Archives Nationales, Paris, AG/3 (1)/ 256: Dossier 1b).
} 
12 Andrew Shennan, Rethinking France: Plans for Renewal, 1940-1946 (Oxford: Clarendon Press, 1989), pp. 9-11.

${ }^{13}$ Lacouture, De Gaulle: The Rebel, p. 213.

${ }^{14}$ Charles de Gaulle, La discorde chez l'ennemi (Paris: Berger-Levrault, 1924); Le Fil de l'épée, (Paris: Berger-Levrault, 1932); La France et son armée (Paris: Librarie Plon, 1938). See also Lacouture, De Gaulle: The Rebel, Chapters 6 and 7.

${ }^{15}$ Heinz Guderian, Achtung Panzer: The Development of Tank Warfare (first published in German in 1937), (London: Cassell, 1992); A rather negative view of Guderian can be found in: Russell Hart, Guderian: Panzer Pioneer or Myth Maker? (Washington DC: Potomac, 2006).

${ }^{16}$ Basil Liddell Hart, Strategy (London: Faber and Faber, 1954); Decisive Wars of History (London: G. Bell and Sons, 1929), and (among many other works); General J.F.C. Fuller, Armament and History: The Influence of Armament on History from the Dawn of Classical Warfare to the End of the Second World War (New York: C. Scribner's Sons, 1945); Decisive Battles of the Western World, 3 volumes, new editions (London: Cassell, 2001).

${ }^{17}$ Lacouture, De Gaulle: The Rebel, pp. 70-72.

${ }^{18}$ De Gaulle, Discorde chez l'ennemi, pp. 7 -8; Lacouture, De Gaulle: The Rebel, p. 70.

${ }^{19}$ De Gaulle, Discorde chez l'ennemi, pp. 27-59.

20 De Gaulle, Discorde chez l'ennemi, p. 144.

${ }^{21}$ Lacouture, De Gaulle: The Rebel, pp. 77-80.

${ }^{22}$ Charles de Gaulle, Le Fil de l'épée (Paris: Plon, 1932).

${ }^{23}$ Messmer and Larcan, Les écrits militaires, pp. 10 and 17.

${ }^{24} \mathrm{My}$ thanks for the remarks of one of the anonymous reviewers who pointed out that the Maginot Line was originally 'envisaged as [a series of] staging areas for future offensive operations; it was only in the late 1930s that they got reconceived as purely defensive systems'.

${ }^{25}$ Charles de Gaulle, Vers l'armée de metier (Paris: Berger-Levrault, 1934).

26 Jean Jaurès, L'armèe nouvelle (Paris: Editions Sociales, 1915) and (Paris: Editions 10/18, 1962).

27 Martin Alexander, The Republic in Danger: General Maurice Gamelin and the politics of French defence, 1933-1940 (Cambridge University Press: 1992), pp. 36-37.

${ }^{28}$ Alexander, The Republic in Danger, esp. Chapter 6, and; Gavin Bailey, The Arsenal of Democracy: Aircraft Supply and the Anglo-American Alliance, 1938-1942 (Edinburgh:

Edinburgh University Press, 2013).

${ }^{29}$ Messmer and Larcan, Les écrits militaires, p. 70.

${ }^{30}$ Elizabeth Kier, Imagining War: French and British Military Doctrine Between the Wars (Princeton NJ: Princeton University Press, 1997); Douglas Porch, 'Military "Culture" and the Fall of France in 1940: A Review Essay', International Security, Vol 24, No. 4, Spring (2000); Alexander, The Republic in Danger, p. 145.

${ }^{31}$ Alfred Fabre-Luce, Journal de la France, Août 1940 - Avril 1942 (Paris: Imprimerie J.E.P., 1942) [full edition published as: Journals de la France, 1939-1944 (Paris: Fayard, 1969)]; Haute Cour (Paris: Julliard, 1962) and; Le Procès de Haute Cour (Paris: Julliard, 1964).

32 Daniel Garbe, Alfred Fabre-Luce: Un non-conformiste dans le tumulte du XXième siècle (Paris: François-Xavier de Guibert, 2009).

${ }^{33}$ De Gaulle, La France et son armée (Paris: Plon, 1938), p. 277.

${ }^{34}$ See Julian Jackson, France: The Dark Years, 1940-1944 (Oxford: Oxford University Press, 2001) for an appreciation of the longevity of his influence. 
${ }^{35}$ For one view of Bergson see: Andrew Williams, 'Waiting for Monsieur Bergson: Nicholas Murray Butler, James T. Shotwell and the French Sage', Diplomacy and Statecraft, Volume 23, Number 2, June 2012 , pp. 236-253.

${ }^{36}$ Messmer and Larcan, Les écrits militaires, pp. 21-22.

${ }^{37}$ Lacouture, De Gaulle: The Rebel, pp. 26 -28.

${ }^{38}$ Ayache, Le retour du Général de Gaulle, Chapter 6.

${ }^{39}$ As Gamelin also wrote about military matters, in his case Etude Philosophique sur l'Art de la Guerre (Paris: R. Chapelot, 1906), which was praised by no less than [future Marshall] Ferdinand Foch, see: Alexander, The Republic in Danger, p. 16.

${ }^{40}$ Alexander, The Republic in Danger, pp. 3-4 and 30.

${ }^{41}$ Régis Debray, De Gaulle: Futurist of the Nation (London: Verso, 1994).

${ }^{42}$ Ayache, Le retour du Général de Gaulle, 1946-1958, pp. 158-161. [Ayache is here quoting from Jean-Reymond Tournoux, La tragédie du Général (Paris: Plon, 1967), p. 140].

${ }^{43}$ Lacouture, De Gaulle: The Ruler, pp. 333-334.

${ }^{44}$ Lacouture, De Gaulle: The Ruler, p.334. 